\title{
Hippocrates to COVID-19
}

\author{
Darner Adrián Mora Alvarado* \\ Clinical Chemical Microbiology, Mater en Salud Public, Brazil \\ *Corresponding author: Darner Adrián Mora Alvarado, Clinical Chemical Microbiology, Mater en Salud Public, Brazil
}

\begin{tabular}{|c|c|}
\hline ARTICLE INFO & ABSTRACT \\
\hline Received: 呲 August 12, 2021 & $\begin{array}{l}\text { Citation: Darner Adrián Mora Alvarado. Hippocrates to COVID-19. Biomed J Sci \& Tech } \\
\text { Res 38(2)-2021. BJSTR. MS.ID.006128. }\end{array}$ \\
\hline
\end{tabular}

\section{Short Communication}

Since ancient times, human beings considered that the climate has influence on the origin and nature of diseases. The relation between climate and health was first attributed to supernatural forces, till Hippocrates in $460 \mathrm{BC}$ refused all these superstitions, legends, and beliefs. Furthermore, he separated medicine from religion, arguing that diseases were not punishments doled out by mythological gods, but consequences from environmental factors, diet, and health habits. Throughout history difference "schools of thought" were developed differing between those who strive to provide a better climate or environment and those who treat diseases, but both seek more "healthier" places than others and indicate which climate changes can increase the vulnerability of a population to certain pathologies. Hippocrates indicated in one of his writings called "Aphorisms" the following:

1. Aphorism 3: Of diseases and ages, certain of them are well- or ill-adapted to different seasons, places, and kinds of diet.

2. Aphorism 19: All diseases occur at all seasons of the year, but certain of them are more apt to occur and be exacerbated at certain seasons.

These aphorisms are a brief statement that expresses a doctrine or principle applicable even now days. Thus, in the current COVID-19 crisis, caused by SARS-CoV-2, it is necessary to analyse whether the transmission of this virus is related the seasons of the year, i.e. summer, winter, autumn, and spring. Studies carried out in different latitudes of the world establish as a hypothesis that SARS-CoV-2 is less transmissible in hot and humid weather, favouring the practice of sports or outdoor exercises and greater exposure to the sun, reactivating the production of vitamin $\mathrm{D}$ essential for the immune system regulation. On the other hand, among the reasons that could support this hypothesis of greater transmission in winter, it may be related to overcrowding, human activity, and greater contact, which increase infections. In Costa Rica, the National Water Laboratory has been conducting two studies: a general study entitled "Weather and Covid-19 in Latin America" and a more specific study on "Solar radiation and Covid-19 in Costa Rica." In the former study preliminary results indicate that of the 51 pandemic waves suffered so far in the 21 countries in Latin America, 24.5\% had their highest peak of infections in summer, $69.8 \%$ in winter $5.7 \%$ in autumn and zero in spring. These results show the Hippocrates aphorisms still apply now days during the COVID-19 crisis. 
ISSN: 2574-1241

DOI: $10.26717 /$ BJSTR.2021.38.006128

Darner Adrián Mora Alvarado. Biomed J Sci \& Tech Res

(c) (P) This work is licensed under Creative

Submission Link: https://biomedres.us/submit-manuscript.php

$\begin{array}{ll}\text { BIOMEDICAL } & \text { Assets of Publishing with us } \\ \text { RESEARCHES } & \text { - Global archiving of articles } \\ \text { - Immediate, unrestricted online access }\end{array}$

